\title{
Leuconostoc spp. Associated with Root Rot in Sugar Beet and Their Interaction with Rhizoctonia solani
}

\author{
Carl A. Strausbaugh
}

United States Department of Agriculture-Agricultural Research Service NWISRL, 3793 North 3600 East, Kimberly, ID 83341. Accepted for publication 30 December 2015.

\begin{abstract}
Strausbaugh, C. A. 2016. Leuconostoc spp. associated with root rot in sugar beet and their interaction with Rhizoctonia solani. Phytopathology 106:432-441.

Rhizoctonia root and crown rot is an important disease problem in sugar beet caused by Rhizoctonia solani and also shown to be associated with Leuconostoc spp. Initial Leuconostoc studies were conducted with only a few isolates and the relationship of Leuconostoc with $R$. solani is poorly understood; therefore, a more thorough investigation was conducted. In total, 203 Leuconostoc isolates were collected from recently harvested sugar beet roots in southern Idaho and southeastern Oregon during

2010 and 2012: 88 and 85\% Leuconostoc mesenteroides, 6 and 15\% L. pseudomesenteroides, 2 and $0 \%$ L. kimchi, and 4 and $0 \%$ unrecognized Leuconostoc spp., respectively. Based on 16S ribosomal RNA sequencing, haplotype 11 (L. mesenteroides isolates) comprised 68 to $70 \%$ of the isolates in both years. In pathogenicity field studies with commercial sugar beet 'B-7', all Leuconostoc isolates caused more rot $(P<0.0001 ; \alpha=$ 0.05 ) when combined with $R$. solani than when inoculated alone in both years. Also, 46 of the 52 combination treatments over the 2 years had significantly more $\operatorname{rot}(P<0.0001 ; \alpha=0.05)$ than the fungal check. The data support the conclusion that a synergistic interaction leads to more rot when both Leuconostoc spp. and $R$. solani are present in sugar beet roots.
\end{abstract}

Rhizoctonia root and crown rot (RRCR) in sugar beet (Beta vulgaris L.) caused by Rhizoctonia solani Kühn is an important disease problem in production areas worldwide, which can lead to yield losses of $50 \%$ or more (Büttner et al. 2004; Führer Ithurrart et al. 2004; Kiewnick et al. 2001; Ohkura et al. 2009; Strausbaugh et al. 2011a). In Treasure Valley, Idaho, RRCR has been observed to lead to almost total crop loss at times due to poor furrow irrigation (taking longer than $24 \mathrm{~h}$ to get water to the end of the field), stress from other diseases such as curly top and rhizomania, and a warmer, longer growing season than the rest of the Idaho production area (Strausbaugh and Gillen 2009; Strausbaugh et al. 2011a). Previous investigations into RRCR with sugar beet roots have identified $R$. solani AG-2-2 IIIB strains to be of primary importance in Idaho and other production areas (Bolton et al. 2010; Buhre et al. 2009; Führer Ithurrart et al. 2004; Kluth et al. 2010; Pfähler and Petersen 2004; Strausbaugh et al. 2011a; Taheri and Tarighi 2012; Windels and Brantner 2005).

Investigations in Idaho established that internal sugar beet root tissue invaded by $R$. solani is frequently associated with bacteria and yeast (Strausbaugh and Gillen 2008). In particular, Leuconostoc mesenteroides subsp. dextranicum (Beijerinck) Garvie has been established as being associated with root rot in sugar beet and can lead to some root rot when inoculated alone (Strausbaugh and Gillen 2008; Strausbaugh et al. 2010). Thus, microbial invasion

Corresponding author: C. A. Strausbaugh;

E-mail address: carl.strausbaugh@ars.usda.gov

GenBank accessions: KT952367 to KT952390.

*The $\boldsymbol{e}$-Xtra logo stands for "electronic extra" and indicates that one supplementary table is published online.

http://dx.doi.org/10.1094/PHYTO-12-15-0325-R

This article is in the public domain and not copyrightable. It may be freely reprinted with customary crediting of the source. The American Phytopathological Society, 2016. associated with RRCR leads to loss of tonnage and reduced sucrose levels in roots in the field. Additional losses can occur in storage piles and factory processing because of extracellular polysaccharides from bacteria and increased impurities in roots (Cescutti et al. 2005; Cogan and Jordan 1994; Strausbaugh et al. 2011b; Tallgren et al. 1999).

Leuconostoc van Tieghem is a gram-positive heterofermentative lactic acid bacterium widely distributed in the environment in locations such as such as soil, plant surfaces, fermented vegetables, dairy products, manure, and wine (Benkerroum et al. 1993; Chen et al. 2005; Cogan and Jordan 1994; Conn et al. 1995; Gardner et al. 2001; Hemme 2012; Holt et al. 1994; Orberg and Sandine 1984; Server-Busson et al. 1999; Zarazaga et al. 1999). Thus, finding Leuconostoc spp. associated with rotted, fermented sugar beet root tissue should not be surprising. Leuconostoc spp. are known to be important in the early stages of fermentation but usually are superseded by other bacteria and yeast at some point during fermentation (Adesogan et al. 2003; Amoa-Awua et al. 2007; Gardner et al. 2001; Jung et al. 2012).

In sugar beet roots, the dry black rot associated with $R$. solani invasion is typically restricted to the surface of the root and the immediate underlying tissue, while the wet, fermented-smelling rot extends into the root and tends to be associated with a range of bacteria and yeast (Strausbaugh and Gillen 2008; Strausbaugh et al. 2011b). A number of the bacteria and yeast associated with rotted sugar beet root tissue can slow or inhibit the growth of $R$. solani, which could explain why $R$. solani is largely restricted to surfacerelated root tissues (Lovic et al. 1993; Strausbaugh and Gillen 2008, 2009). When these bacteria and yeast were inoculated individually back into sugar beet root tissue, L. mesenteroides subsp. dextranicum was determined to be associated with the most rot (Strausbaugh and Gillen 2008). However, these previous Leuconostoc investigations included a limited number of strains and were conducted with whole roots removed from the ground or in the laboratory with root slices, which led to data that were correlated with storage rather than the field (Strausbaugh and Gillen 2008; Strausbaugh et al. 2013a). 
Thus, a more thorough investigation focused on Leuconostoc spp. needed to be conducted to determine the Leuconostoc sp. and distribution of these species in commercial sugar beet production areas. Also, the association of the genus Leuconostoc with $R$. solani in sugar beet root tissue needs to be investigated. To achieve these goals, isolates of Leuconostoc were collected from recently harvested roots originating from commercial sugar beet fields in southern Idaho and southeastern Oregon in The Amalgamated Sugar Company LLC (TASCO) production area to establish the species and diversity in Leuconostoc associated with RRCR. Genetically diverse representative isolates were then utilized in pathogenicity studies conducted in the field to improve our knowledge of the role of genus Leuconostoc in sugar beet root rots and how it may interact with $R$. solani.

\section{MATERIALS AND METHODS}

Survey of sugar beet roots with rot. From 27 October to 3 November 2010, 53 storage piles at receiving stations from Declo, ID to Vale, OR were visually evaluated for RRCR. From these piles, 451 symptomatic roots were arbitrarily collected. From this collection, 120 roots were arbitrarily selected for isolation to give representation to all areas. In 2012, the survey was repeated from 30 October to 15 November by collecting roots from 56 storage piles covering the same production area covered in 2010. From these piles, 619 symptomatic roots were collected and 200 were arbitrarily selected for isolation to give representation to all areas.

TABLE 1. GenBank accessions included in the phylogenetic analyses for the 16S ribosomal RNA locus of Leuconostoc spp.

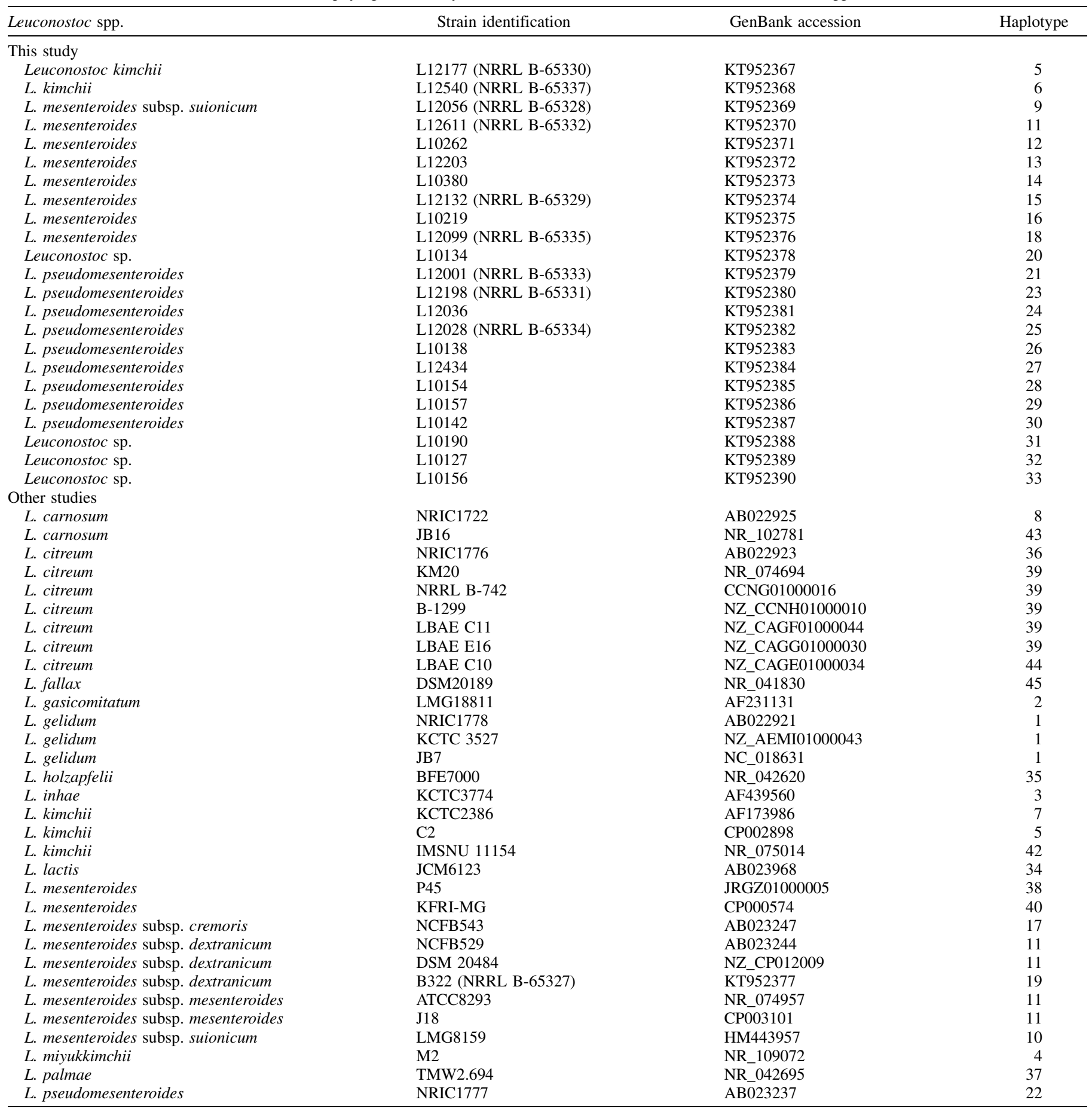


Isolations. To collect Leuconostoc spp., isolations from the leading edge of rotted areas in sugar beet root tissue were conducted on glucose-yeast extract-peptone agar (GYP) (glucose, $10.0 \mathrm{~g}$; yeast extract, $5.0 \mathrm{~g}$; peptone, $5.0 \mathrm{~g}$; sodium acetate $2.0 \mathrm{~g}$; Tween $80,0.25 \mathrm{~g}$; $\mathrm{MgSO}_{4} \cdot 7 \mathrm{H}_{2} \mathrm{O}, 0.2 \mathrm{~g} ; \mathrm{MnSO}_{4} \cdot 4 \mathrm{H}_{2} \mathrm{O}, 0.01 \mathrm{~g} ; \mathrm{FeSO}_{4} \cdot 7 \mathrm{H}_{2} \mathrm{O}, 0.01 \mathrm{~g}$;

TABLE 2. Root rot in sugar beet roots of the commercial cultivar B-7 inoculated with 26 Leuconostoc isolates with and without Rhizoctonia solani AG-2-2 IIIB strain F517 along with fungal and water checks in 2014 and 2015 Kimberly, ID field studies ${ }^{v}$

\begin{tabular}{|c|c|c|c|}
\hline \multirow[b]{2}{*}{ Treatment $^{\mathrm{x}}$} & \multirow[b]{2}{*}{ Haplotype ${ }^{y}$} & \multicolumn{2}{|c|}{ Root rot $(\mathrm{mm})^{\mathrm{w}}$} \\
\hline & & 2014 & 2015 \\
\hline L12177 + F517 & 5 & $12 \mathrm{j}-\mathrm{o}$ & $40 \mathrm{a}$ \\
\hline L12174 + F517 & 21 & $19 \mathrm{~d}-\mathrm{k}$ & $38 \mathrm{ab}$ \\
\hline $\mathrm{L} 12311+\mathrm{F} 517$ & 11 & $26 b-g$ & $37 \mathrm{a}-\mathrm{c}$ \\
\hline $\mathrm{L} 12431+\mathrm{F} 517$ & 30 & $14 \mathrm{~h}-1$ & $35 \mathrm{a}-\mathrm{d}$ \\
\hline L12388 + F517 & 11 & $23 \mathrm{c}-\mathrm{h}$ & $35 \mathrm{a}-\mathrm{d}$ \\
\hline L12487 + F517 & 23 & $16 \mathrm{~g}-\mathrm{k}$ & $33 \mathrm{a}-\mathrm{d}$ \\
\hline L12028 + F517 & 25 & $21 \mathrm{~d}-\mathrm{j}$ & $32 \mathrm{a}-\mathrm{f}$ \\
\hline L12113 + F517 & 23 & $24 \mathrm{c}-\mathrm{g}$ & $31 \mathrm{a}-\mathrm{f}$ \\
\hline L12099 + F517 & 18 & $27 \mathrm{~b}-\mathrm{e}$ & $31 \mathrm{a}-\mathrm{f}$ \\
\hline L12040 + F517 & 23 & $29 \mathrm{a}-\mathrm{d}$ & $31 \mathrm{a}-\mathrm{f}$ \\
\hline L12203 + F517 & 13 & $18 \mathrm{e}-\mathrm{k}$ & $31 \mathrm{a}-\mathrm{f}$ \\
\hline L12048 + F517 & 11 & $38 \mathrm{a}$ & $30 \mathrm{~b}-\mathrm{f}$ \\
\hline L12198 + F517 & 23 & $23 \mathrm{c}-\mathrm{h}$ & $30 \mathrm{~b}-\mathrm{f}$ \\
\hline $\mathrm{L} 12347$ + F517 & 11 & $16 \mathrm{~g}-\mathrm{k}$ & $29 \mathrm{~b}-\mathrm{f}$ \\
\hline L12384 + F517 & 15 & $31 \mathrm{a}-\mathrm{c}$ & $29 \mathrm{c}-\mathrm{f}$ \\
\hline $\mathrm{L} 12001+\mathrm{F} 517$ & 21 & $12 \mathrm{j}-\mathrm{n}$ & $28 \mathrm{c}-\mathrm{f}$ \\
\hline L12199 + F517 & 21 & $20 \mathrm{~d}-\mathrm{j}$ & $28 \mathrm{c}-\mathrm{f}$ \\
\hline L12544 + F517 & 15 & $23 \mathrm{~d}-\mathrm{i}$ & $28 \mathrm{~d}-\mathrm{f}$ \\
\hline L12434 + F517 & 27 & $16 \mathrm{f}-\mathrm{k}$ & $27 \mathrm{~d}-\mathrm{f}$ \\
\hline $\mathrm{L} 12443+\mathrm{F} 517$ & 21 & $16 \mathrm{~g}-\mathrm{k}$ & $27 \mathrm{~d}-\mathrm{f}$ \\
\hline L12036 + F517 & 24 & $23 \mathrm{~d}-\mathrm{i}$ & $26 \mathrm{~d}-\mathrm{f}$ \\
\hline L12056 + F517 & 9 & $17 \mathrm{e}-\mathrm{k}$ & $26 \mathrm{~d}-\mathrm{f}$ \\
\hline $\mathrm{L} 12540+\mathrm{F} 517$ & 6 & $20 \mathrm{~d}-\mathrm{j}$ & $25 \mathrm{e}-\mathrm{g}$ \\
\hline B322 + F517 & 19 & $27 \mathrm{~b}-\mathrm{f}$ & $25 \mathrm{e}-\mathrm{g}$ \\
\hline $\mathrm{L} 12132+\mathrm{F} 517$ & 15 & $35 \mathrm{ab}$ & $25 \mathrm{e}-\mathrm{g}$ \\
\hline L12611 + F517 & 11 & $25 \mathrm{~b}-\mathrm{g}$ & $23 \mathrm{f}-\mathrm{h}$ \\
\hline Water + F517 & NA & $2 m-p$ & $16 \mathrm{~g}-\mathrm{i}$ \\
\hline L12311 & 11 & $41-p$ & $14 \mathrm{~h}-\mathrm{j}$ \\
\hline L12099 & 18 & $1 \mathrm{p}$ & $13 \mathrm{i}-\mathrm{k}$ \\
\hline L12113 & 23 & $0 \mathrm{p}$ & $11 \mathrm{i}-1$ \\
\hline L12443 & 21 & $0 \mathrm{p}$ & $11 \mathrm{i}-1$ \\
\hline L12132 & 15 & $10 \mathrm{k}-\mathrm{p}$ & $10 \mathrm{i}-1$ \\
\hline L12434 & 27 & $1 \mathrm{p}$ & $10 \mathrm{i}-1$ \\
\hline L12048 & 11 & $1 \mathrm{p}$ & $10 \mathrm{i}-1$ \\
\hline L12040 & 23 & $0 \mathrm{p}$ & $9 \mathrm{i}-\mathrm{m}$ \\
\hline L12203 & 13 & $51-p$ & $9 \mathrm{i}-\mathrm{m}$ \\
\hline L12388 & 11 & $41-p$ & $9 \mathrm{i}-\mathrm{m}$ \\
\hline B322 & 19 & 2 op & $9 \mathrm{i}-\mathrm{m}$ \\
\hline L12036 & 24 & $0 \mathrm{p}$ & $9 \mathrm{i}-\mathrm{m}$ \\
\hline L12384 & 15 & $41-p$ & $9 \mathrm{i}-\mathrm{m}$ \\
\hline L12431 & 30 & $0 \mathrm{p}$ & $8 \mathrm{i}-\mathrm{m}$ \\
\hline L12611 & 11 & $13 \mathrm{i}-\mathrm{m}$ & $8 \mathrm{i}-\mathrm{m}$ \\
\hline L12028 & 25 & $0 \mathrm{p}$ & $8 \mathrm{i}-\mathrm{m}$ \\
\hline L12199 & 21 & $0 \mathrm{p}$ & $8 \mathrm{i}-\mathrm{m}$ \\
\hline L12347 & 11 & $0 \mathrm{p}$ & $8 \mathrm{i}-\mathrm{m}$ \\
\hline L12544 & 15 & $51-p$ & $8 \mathrm{i}-\mathrm{m}$ \\
\hline L12174 & 21 & $1 \mathrm{p}$ & $8 \mathrm{i}-\mathrm{m}$ \\
\hline L12487 & 23 & $1 \mathrm{p}$ & $8 \mathrm{i}-\mathrm{m}$ \\
\hline L12177 & 5 & $0 \mathrm{p}$ & $6 \mathrm{j}-\mathrm{m}$ \\
\hline L12001 & 21 & $0 \mathrm{p}$ & $5 j-m$ \\
\hline L12540 & 6 & $0 \mathrm{p}$ & $4 \mathrm{k}-\mathrm{m}$ \\
\hline L12056 & 9 & $2 n-p$ & $4 \mathrm{~lm}$ \\
\hline L12198 & 23 & 2 op & $4 \mathrm{~lm}$ \\
\hline Water & NA & $0 \mathrm{p}$ & $0 \mathrm{~m}$ \\
\hline$P>F^{\mathrm{z}}$ & NA & $<0.0001$ & $<0.0001$ \\
\hline
\end{tabular}

${ }^{v}$ Means followed by the same letter within a column did not differ significantly based on least square means $(\alpha=0.05)$. NA = not applicable.

${ }^{w}$ Internal root rot measured inside a bisected sugar beet.

x Twenty-six strains of Leuconostoc were evaluated with and without Rhizoctonia solani AG-2-2 IIIB strain F517 along with F517 alone (in bold) and noninoculated water check (in bold).

y Haplotype was based on sequencing (1,437 to $1,440 \mathrm{bp}$ ) from the $16 \mathrm{~S}$ ribosomal RNA region.

${ }^{\mathrm{z}} P>F$ was the probability associated with the $\mathrm{F}$ value.
$\mathrm{NaCl}, 5.0 \mathrm{~g} ; \mathrm{CaCO}_{3}, 5.0 \mathrm{~g}$; agar, $20 \mathrm{~g}$; and reverse osmosis water, $1,000 \mathrm{ml}$; adjusted to $\mathrm{pH} 6.8)$, with bromocresol purple (0.04 g/liter) amended with tetracycline $(0.2 \mathrm{mg} /$ liter $)$ and vancomycin $(0.03$ $\mathrm{g} /$ liter) to make it semiselective for Leuconostoc spp. (Benkerroum et al. 1993; Cai et al. 1999).

Molecular characterization of Leuconostoc isolates. To further characterize the 203 Leuconostoc isolates, these isolates (Supplementary Table S1) along with 2 isolates from other studies-B322 (Strausbaugh and Gillen 2008) and B853 (from the 2012 Rhizoctonia Root Rot Nursery in Kimberly, ID)—were investigated by sequencing 1,437 to $1,440 \mathrm{bp}$ of the $16 \mathrm{~S}$ ribosomal RNA (rRNA) locus. To obtain DNA, the isolates were grown in de Man, Rogosa, and Sharpe (MRS) broth (EMD Chemicals Inc., Gibbstown, NJ) in shake culture at $140 \mathrm{rpm}$ and $30^{\circ} \mathrm{C}$ for $48 \mathrm{~h}$. The bacteria were then pelleted at $8,000 \mathrm{rpm}$, resuspended in moleculargrade water (5 Prime, Gaithersburg, MD), and stored at $-80^{\circ} \mathrm{C}$. The polymerase chain reactions (PCR) were performed in volumes of $30 \mu \mathrm{l}$ in accordance with the manufacturer's instructions: $15.35 \mu \mathrm{l}$ of molecular-grade water (5 Prime Inc.), $6 \mu \mathrm{l}$ of $5 \times$ PCR GoTaq buffer (Promega Corp., Madison, WI), $0.8 \mu \mathrm{l}$ of $25 \mathrm{mM} \mathrm{MgCl}_{2}$ (Applied Biosystems, Forster City, CA), $0.6 \mu \mathrm{l}$ of $10 \mathrm{mM}$ dNTP (Promega Corp.), $2.5 \mu \mathrm{l}$ of $3 \mu \mathrm{M}$ each primer (Integrated DNA Technologies, Coralville, IA), $0.25 \mu \mathrm{l}$ of GoTaq Taq DNA polymerase, and $2 \mu \mathrm{l}$ (approximately $10^{8}$ cells $/ \mathrm{ml}$ ) of target DNA. The amplification cycle consisted of $3 \mathrm{~min}$ at $95^{\circ} \mathrm{C}$ followed by 35 cycles of $95^{\circ} \mathrm{C}$ for $30 \mathrm{~s}$, a $66^{\circ} \mathrm{C}$ annealing temperature for $30 \mathrm{~s}$, and $72^{\circ} \mathrm{C}$ for $1 \mathrm{~min}$. The final cycle was followed by $72^{\circ} \mathrm{C}$ for $5 \mathrm{~min}$ and then held at $4^{\circ} \mathrm{C}$. The primer sequence pairs were E8F (AGAGTTTGATCCTGGCTCAG) and E939R (CTTGTGCGGGCCCCCGTCAATTC) plus E786F (GAT TAGATACCCTGGTAG) and U1510R (GGTTACCTTGTTACGA CTT) (Baker et al. 2003; Coloqhoun 1997; Lopez-Garcia et al.

TABLE 3. Survey summary of 203 Leuconostoc isolates collected at the end of the 2010 and 2012 growing seasons from sugar beet roots with the Rhizoctonia-bacteria root rot complex located in the Amalgamated Sugar Company's production area in southern Idaho and southeastern Oregon

\begin{tabular}{|c|c|c|c|}
\hline \multirow[b]{2}{*}{ Leuconostoc spp. ${ }^{\mathrm{y}}$} & \multirow[b]{2}{*}{ Haplotype } & \multicolumn{2}{|c|}{ Isolates $(\%)^{\mathrm{x}}$} \\
\hline & & 2010 & 2012 \\
\hline \multirow{8}{*}{ Leuconostoc mesenteroides } & 9 & 0 & 2 \\
\hline & 11 & 70 & 66 \\
\hline & 12 & 1 & 0 \\
\hline & 13 & 0 & 1 \\
\hline & 14 & 1 & 0 \\
\hline & 15 & 11 & 15 \\
\hline & 16 & 4 & 0 \\
\hline & 18 & 1 & 1 \\
\hline Total & $\ldots$ & 88 & 85 \\
\hline \multirow[t]{9}{*}{ L. pseudomesenteroides } & 21 & 0 & 4 \\
\hline & 23 & 1 & 5 \\
\hline & 24 & 0 & 1 \\
\hline & 25 & 0 & 3 \\
\hline & 26 & 1 & 0 \\
\hline & 27 & 0 & 1 \\
\hline & 28 & 1 & 0 \\
\hline & 29 & 1 & 0 \\
\hline & 30 & 1 & 1 \\
\hline Total & $\ldots$ & 6 & 15 \\
\hline \multirow[t]{2}{*}{ L. kimchii } & 5 & 1 & 0 \\
\hline & 6 & 1 & 0 \\
\hline Total & $\ldots$ & 2 & 0 \\
\hline \multirow[t]{4}{*}{ Leuconostoc sp. } & 20 & 1 & 0 \\
\hline & 31 & 1 & 0 \\
\hline & 32 & 1 & 0 \\
\hline & 33 & 1 & 0 \\
\hline Total & $\ldots$ & 4 & 0 \\
\hline
\end{tabular}

x Number of Leuconostoc isolates that fell in the different haplotypes based on 72 and 131 isolates collected in 2010 and 2012, respectively.

y Haplotype association with Leuconostoc spp. identified on the phylogram based on sequencing from the $16 \mathrm{~S}$ ribosomal RNA locus.

$\mathrm{z}$ Haplotypes identified based on sequencing from the $16 \mathrm{~S}$ ribosomal RNA locus. 
2001; Martínez-Murcia et al. 1995; Reysenbach and Pace 1995; Reysenbach et al. 1994; Rudi et al. 1997; Tajima et al. 2001). Amplification products were electrophoresed through agarose gels $(1.8 \% \mathrm{wt} / \mathrm{vol})$ supplemented with ethidium bromide $(0.01 \mathrm{mg} / \mathrm{ml})$ in Tris-borate EDTA buffer $(89 \mathrm{mM}$ Tris base, $89 \mathrm{mM}$ boric acid, and $2 \mathrm{mM}$ EDTA). Amplicons were sent to TACGen (Richmond, CA) for PCR cleanup to remove any excess dNTP and unincorporated primers, and for sequencing in both directions. Sequences were evaluated using BioEdit, version 7.1.3.0 (Hall 1999) and representative haplotypes were submitted to GenBank (accessions KT952367 to KT952390). DNA sequences were aligned using ClustalX, version 2.0 (Larkin et al. 2007).
Phylogenetic analysis. The phylogenetic analyses were conducted using the GenBank accessions found in Table 1. The maximum parsimony analysis was performed using PAUP (version 4.0b10; Sinauer Associates, Inc., Sunderland, MA) with the heuristic search, simple taxon addition sequences, tree bisection-reconnection branch swapping, and MaxTrees = 100. Statistical support was determined for the analyses by bootstrap values for 1,000 replicates. MEGA 6.05 (Tamura et al. 2011) was used to determine the substitution model that best fit the data according to the Akaike Information Criterion. The T92 (Tamura three-parameter model) + $\mathrm{G}+\mathrm{I}$ model was selected. Maximum-likelihood analyses were conducted with MEGA, with an initial search (two replicates) used

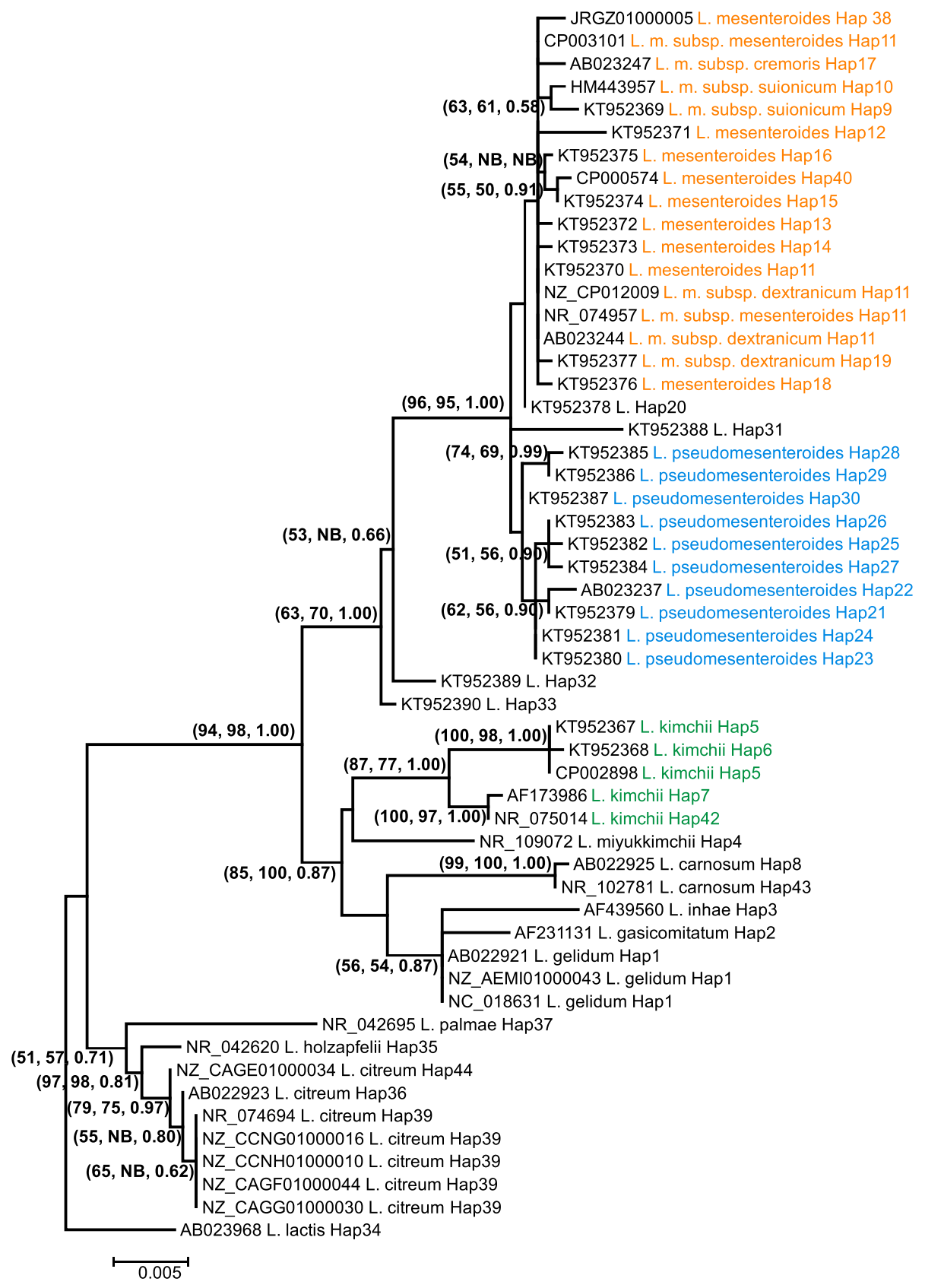

Fig. 1. Phylogenetic relationships among 205 Leuconostoc isolates collected from rot in sugar beet roots in Idaho and Oregon based on sequences (1,437 to $1,440 \mathrm{bp}$ ) from the $16 \mathrm{~S}$ ribosomal RNA region. Numbers on nodes of the maximum-likelihood (ML) phylogram represent the statistical support for ML (1,000 replicates, left number), maximum parsimony $(1,000$ bootstrap replicates, middle number), and Bayesian method (posterior probabilities, right number). NB $=$ no branch in that analysis. Leuconostoc strains in the phylogram are designated by GenBank accession number followed by name and haplotype. Leuconostoc fallax (very distantly related to the other Leuconostoc spp.) was excluded from the analysis to avoid compressing the phylogram. Most isolates (86\%) fall in the Leuconostoc mesenteroides group (orange), while the Leuconostoc pseudomesenteroides group (blue) and Leuconostoc kimchi group (green) represent 10 and $1 \%$ of the isolates, respectively. Haplotype 11 was most prevalent, representing $67 \%$ of the isolates. 
to estimate the model parameters. The parameters were then fixed for a bootstrap analysis of 1,000 replicates. The Bayesian phylogenetic analyses were conducted with MrBayes 3.2.1 (Ronquist and Huelsenbeck 2003), with two searches run simultaneously until the standard deviation of split frequencies fell below 0.01 . The analysis was conducted using the default priors. The majority-rule consensus was then calculated after removing the first $25 \%$ of generations as burn-in. The trees were visualized using FigTree (version 1.4.0; Institute of Evolutionary Biology, University of Edinburgh, Edinburgh, UK).

Carbon source utilization. Representative isolates for the 12 most common haplotypes were evaluated for carbon source utilization using GenIII MicroPlates (Biolog Inc., Hayward, CA). The protocols suggested by the manufacturer were followed and the assays were repeated once.

2014 Field study. The 2014 field study was planted in a field located in Twin Falls County on the United States Department of Agriculture-Agricultural Research Service North Farm $\left(42^{\circ} 33.172^{\prime} \mathrm{N}\right.$, $114^{\circ} 21.525^{\prime} \mathrm{W}$, elevation $1,190 \mathrm{~m}$ ) near Kimberly, ID, which has Portneuf silt loam soil and had been in barley the previous year. The field was disked and plowed in fall 2013. Fertilizer ( $\mathrm{N}$ at $100.8 \mathrm{~kg} / \mathrm{ha}$ and $\mathrm{P}_{2} \mathrm{O}_{5}$ at $123.3 \mathrm{~kg} / \mathrm{ha}$ ) was applied on 11 April and incorporated with a roller harrow. The commercial sugar beet 'B-7' (Betaseed Inc., Kimberly, ID), susceptible to RRCR (C. A. Strausbaugh, unpublished data), was planted 21 April to a density of 352,272 seeds/ha and thinned to 117,424 plants/ha on 31 May. There were $56 \mathrm{~cm}$ between rows. Irrigation water was applied through hand lines as needed to replace evapotranspiration, based on data from the Twin Falls AgriMet station (station TWFI; elevation 1,197 m, $42^{\circ} 32.746^{\prime} \mathrm{N}, 114^{\circ} 20.762^{\prime} \mathrm{W}, 1.32 \mathrm{~km}$ from plots). The field was managed using standard cultural practices for Idaho as mentioned in the 2014 Sugarbeet grower's guide book (TASCO, Boise, ID). The experiment was arranged in a randomized complete block design with six replications. In total, there were 54 treatments: a water check; a fungal check, $R$. solani AG-2-2 IIIB strain F517 (Strausbaugh et al. 2011a) inoculated with water; 26 Leuconostoc isolates (Table 2) inoculated individually; and the same 26 Leuconostoc isolates inoculated with $R$. solani strain F517. These bacterial isolates represented a cross section of the haplotypes from the TASCO production area affected by RRCR. Each individual root served as an experimental unit. A cork borer plug $(8 \mathrm{~mm}$ in diameter by $24 \mathrm{~mm}$ deep) on the shoulder of the root was pulled on 13 August to allow for inoculation. For the water check, $0.2 \mathrm{ml}$ of sterile well water was placed in the hole. For the fungal check, $0.06 \mathrm{~g}$ of dried barley inoculum, prepared as described by Strausbaugh et al. (2013a), of $R$. solani AG-2-2 IIIB strain F517 was placed in the hole with $0.2 \mathrm{ml}$ of sterile well water. For the bacterial inoculations, $0.2 \mathrm{ml}$ of a Leuconostoc strain suspension $\left(10^{8} \mathrm{CFU} / \mathrm{ml}\right)$, prepared

TABLE 4. Carbon source utilization assays for 12 Leuconostoc isolates from different haplotypes

\begin{tabular}{|c|c|c|c|c|c|c|c|c|c|c|c|c|}
\hline \multirow[b]{2}{*}{ Carbon sources ${ }^{\mathrm{z}}$} & \multicolumn{12}{|c|}{ Leuconostoc haplotypes ${ }^{\mathrm{y}}$} \\
\hline & 5 & 6 & 9 & 11 & 15 & 18 & 19 & 21 & 23 & 24 & 25 & 30 \\
\hline Acetic acid (H8) & + & + & $\mathrm{D}$ & + & + & + & $\mathrm{D}$ & + & + & + & + & + \\
\hline Acetoacetic acid (H6) & + & + & + & + & + & + & + & + & + & + & - & + \\
\hline L-alanine (E3) & - & - & - & - & - & - & - & - & - & - & - & - \\
\hline D-arabitol (D3) & - & - & - & - & - & - & - & - & - & - & - & - \\
\hline L-arginine (E4) & - & - & - & - & - & - & - & - & - & - & - & - \\
\hline D-aspartic acid (D8) & - & - & - & - & - & - & - & - & - & - & - & - \\
\hline L-aspartic acid (E5) & - & - & - & - & - & - & - & - & - & - & - & - \\
\hline$\gamma$-Amino-butyric acid (H2) & - & - & - & - & - & - & - & - & - & - & - & - \\
\hline$\alpha$-Hydroxy-butyric acid (H3) & - & - & - & - & - & - & - & - & - & - & - & - \\
\hline$\beta$-Hydroxy-D,L-butyric acid (H4) & - & - & - & - & - & - & - & - & - & - & - & - \\
\hline$\alpha$-Keto-butyric acid (H5) & - & - & $\mathrm{D}$ & + & - & + & - & - & + & - & + & + \\
\hline D-cellobiose (A5) & + & + & + & + & + & + & + & + & + & + & + & + \\
\hline Citric acid (G5) & - & - & - & - & - & - & - & - & - & - & - & - \\
\hline Dextrin (A2) & + & + & + & + & + & + & + & + & + & + & + & + \\
\hline Formic acid (H9) & - & - & - & - & - & - & - & - & - & - & - & - \\
\hline D-fructose (C3) & + & + & + & + & + & + & + & + & + & + & + & + \\
\hline D-fructose-6-PO4 (D7) & - & - & - & - & - & - & - & $\mathrm{D}$ & - & - & - & $\mathrm{D}$ \\
\hline D-fucose (C6) & + & + & - & $\mathrm{D}$ & $\mathrm{D}$ & + & - & + & + & + & + & + \\
\hline L-fusose (C7) & - & - & - & - & - & - & - & - & - & - & - & - \\
\hline N-acetyl-D-galactosamine (B8) & - & - & - & - & - & $\mathrm{D}$ & $\mathrm{D}$ & $\mathrm{D}$ & - & $\mathrm{D}$ & + & $\mathrm{D}$ \\
\hline D-galactose (C4) & - & - & - & + & + & + & - & + & + & + & + & + \\
\hline D-galacturonic acid (F2) & - & - & - & - & - & - & - & - & - & - & - & - \\
\hline L-galacturonic acid lactone (F3) & - & - & - & - & - & - & - & - & - & - & - & - \\
\hline Gelatin (E1) & - & - & - & - & - & - & - & - & - & - & - & - \\
\hline Gentiobiose (A6) & + & + & + & + & + & + & + & + & + & + & + & + \\
\hline D-gluconic acid (F4) & + & + & - & + & + & + & + & + & + & + & + & + \\
\hline $\mathrm{N}$-acetyl-D-glucosamine (B6) & + & + & + & + & + & + & + & + & + & + & + & + \\
\hline$\alpha-\mathrm{D}$-glucose $(\mathrm{C} 1)$ & + & + & + & + & + & + & + & + & + & + & + & + \\
\hline 3-Methyl-glucose (C5) & - & - & - & - & - & $\mathrm{D}$ & - & $\mathrm{D}$ & $\mathrm{D}$ & $\mathrm{D}$ & + & $\mathrm{D}$ \\
\hline$\beta$-Methyl-D-glucoside (B4) & + & + & + & + & + & + & + & + & + & + & + & + \\
\hline Glucuronamide (F6) & - & - & - & - & - & - & - & - & - & - & - & - \\
\hline D-glucuronic acid (F5) & - & - & - & - & - & - & - & - & - & - & - & - \\
\hline L-glutamic acid (E6) & - & - & - & - & - & - & - & - & - & - & - & - \\
\hline$\alpha$-Keto-glutaric acid (G6) & - & - & - & - & - & - & - & - & - & - & - & - \\
\hline Glycerol (D5) & - & - & - & - & - & - & - & - & - & - & - & - \\
\hline L-histidine (E7) & - & - & - & - & - & - & - & - & - & - & - & - \\
\hline
\end{tabular}

${ }^{\mathrm{y}}$ Haplotypes were established using sequencing from the 16S ribosomal RNA locus, as demonstrated in the phylogenetic analysis shown in Figure 1. In the carbon source utilization, the haplotypes were represented by the following Leuconostoc isolates: $5=\mathrm{L} 12177,6=\mathrm{L} 12540,9=\mathrm{L} 12056,11=\mathrm{L} 12611,15=$ L12132, 18 = L12099, 19 = B322, $21=\mathrm{L} 12001,23=\mathrm{L} 12198,24=\mathrm{L} 12036,25=\mathrm{L} 12028$, and $30=\mathrm{L} 12431$. Symbols: $+=$ positive, D = delayed response, and $-=$ negative.

${ }^{z}$ Carbon source utilization for the Leuconostoc haplotypes came from GenIII MicroPlates (Biolog Inc., Hayward, CA). The designation in parentheses following the carbon source name is the microplate location. 
as described by Strausbaugh et al. (2013a), was placed in the hole. For the Leuconostoc $+R$. solani combination inoculation, both the bacterial and fungal isolates or strains were placed in the hole using the same amount as the individual inoculations. The plug was then replaced following inoculation and sealed with petroleum jelly (UNILIVER, Greenwich, CT). On 16 September, roots were dug by hand and bisected through the inoculation site to measure the rot with a ruler perpendicular to the plug. In all, 32 isolations (6 from fungal checks, 6 from bacterial-only treatments, and 20 from the combination treatments) from the leading edge of the rot from arbitrarily selected roots were conducted on fungal and bacterial media. The fungal isolations were conducted on potato dextrose agar (PDA) amended with streptomycin sulfate $\left(200 \mathrm{mg} \mathrm{liter}^{-1}\right)$ and the bacterial isolations were conducted on GYP amended with tetracycline $(0.2 \mathrm{mg} / \mathrm{liter})$, and vancomycin ( $0.03 \mathrm{~g} / \mathrm{liter})$, as described above.

2015 Field study. The 2015 field study was planted in a different section of the same field as the 2014 field study using the same methods. This section of the field had been in barley in 2014 and was fertilized ( $\mathrm{N}$ at $100.8 \mathrm{~kg} / \mathrm{ha}$ and $\mathrm{P}_{2} \mathrm{O}_{5}$ at $123.3 \mathrm{~kg} / \mathrm{ha}$ ) on 9 April 2015. The field was planted on 20 April and thinned on 29 May. The roots were inoculated on 12 August and ratings and isolations were conducted on 10 September.

Data analysis. The SAS univariate procedure (SAS version 9.2; SAS Institute Inc., Cary, NC) was used to test for normality of the data. Data were also subjected to analysis of variance using the SAS generalized linear mixed-models procedure (Proc GLIMMIX). In the model statement, the fixed effect was treatment and the random effect was block. In the model statement, the denominator degrees of freedom were calculated using the DDFM = KENWARDRODGER option. Mean comparisons were conducted using least square means $(\alpha=0.05)$.

\section{RESULTS}

Survey isolations. In 2010, a collection of 72 Leuconostoc isolates was obtained from 120 root isolations. In 2012, a collection of 131 Leuconostoc isolates was obtained from 200 root isolations.

16S rRNA sequencing. The 205 isolates (203 isolates from survey along with B-322 and B-853 from other studies) were further characterized by sequencing 1,437 to $1,440 \mathrm{bp}$ of the $16 \mathrm{~S}$ rRNA locus (GenBank accessions KT952367 to KT952390). The isolates fell into 23 haplotypes and were associated with the following Leuconostoc spp. during 2010 and 2012: 88 and 85\% L. mesenteroides, 6 and $15 \%$ L. pseudomesenteroides Farrow, 2 and 0\% L. kimchi Kim, and 4 and $0 \%$ unrecognized Leuconostoc sp., respectively (Table 3). The most dominant haplotype found was $L$. mesenteroides Hap 11, which accounted for $70 \%$ of the isolates in 2010 and $66 \%$ of the isolates in 2012. L. mesenteroides Hap15 was the second most common haplotype but represented only 11 and $15 \%$ of the isolates in 2010 and 2012, respectively. The other 21 haplotypes had a frequency of only 0 to $5 \%$, depending on haplotype and year.

Phylogenetic analyses. Phylogenetic analyses were conducted to compare these 23 survey haplotypes with those associated with currently recognized Leuconostoc spp. However, the phylogram was compressed by L. fallax Martinez-Murcia \& Collins (data not shown). Thus, L. fallax was dropped from the analyses and not included in the results presented in Figure 1. The isolates in Figure 1 congregated primarily into three clusters associated with these Leuconostoc spp.: L. mesenteroides, L. pseudomesenteroides, and L. kimchii. The isolates associated with Hap20, Hap31, Hap32, and Hap33 may represent previously unrecognized Leuconostoc spp. or subspecies.

TABLE 4. (continued from preceding page)

\begin{tabular}{|c|c|c|c|c|c|c|c|c|c|c|c|c|}
\hline \multirow[b]{2}{*}{ Carbon sources ${ }^{\mathrm{z}}$} & \multicolumn{12}{|c|}{ Leuconostoc haplotypes ${ }^{\mathrm{y}}$} \\
\hline & 5 & 6 & 9 & 11 & 15 & 18 & 19 & 21 & 23 & 24 & 25 & 30 \\
\hline Inosine (C9) & - & $\mathrm{D}$ & - & - & - & + & - & + & + & + & + & + \\
\hline myo-Inositol (D4) & - & - & - & - & - & - & - & - & - & - & - & - \\
\hline D-lactic acid methyl ester (G3) & - & - & - & - & - & - & - & - & - & - & - & - \\
\hline L-lactic acid (G4) & - & - & - & - & - & - & - & - & - & - & - & - \\
\hline$\alpha$-D-lactose (B2) & - & - & - & - & $\mathrm{D}$ & + & $\mathrm{D}$ & + & $\mathrm{D}$ & + & + & + \\
\hline N-acetyl-neuraminic acid (B9) & - & - & - & - & - & - & - & - & - & - & - & - \\
\hline D-malic acid (G7) & - & - & - & - & - & - & - & - & - & - & - & - \\
\hline L-malic acid (G8) & - & - & - & - & - & - & - & - & - & - & - & - \\
\hline D-maltose (A3) & + & + & $\mathrm{D}$ & + & + & + & + & + & + & + & + & + \\
\hline D-mannitol (D2) & + & + & + & + & $\mathrm{D}$ & - & + & + & - & + & - & - \\
\hline $\mathrm{N}$-acetyl- $\beta$-D-mannosamine (B7) & - & - & - & - & - & - & $\mathrm{D}$ & $\mathrm{D}$ & - & + & + & $\mathrm{D}$ \\
\hline D-mannose (C2) & + & + & + & + & + & + & + & + & + & + & + & + \\
\hline D-melibiose (B3) & - & - & $\mathrm{D}$ & + & + & + & + & + & + & + & + & + \\
\hline Mucic acid (F7) & - & - & - & - & - & - & - & - & - & - & - & - \\
\hline Pectin $(\mathrm{F} 1)$ & + & + & + & + & + & + & + & + & + & + & + & + \\
\hline p-Hydroxy-phenylacetic acid (G1) & - & - & - & - & - & - & - & - & - & - & - & - \\
\hline Glycyl-L-proline (E2) & - & - & - & - & - & - & - & - & - & - & - & - \\
\hline Propionic acid (H7) & - & - & - & - & - & - & - & - & - & - & - & - \\
\hline L-pyroglutamic acid (E8) & - & - & - & - & - & - & - & - & - & - & - & - \\
\hline Methyl pyruvate (G2) & - & - & - & - & - & - & - & - & - & - & - & - \\
\hline Quinic acid (F8) & - & - & - & - & - & - & - & - & - & - & - & - \\
\hline D-raffinose (B1) & - & - & - & + & + & + & + & + & + & + & + & + \\
\hline D-rhamnose (C8) & - & $\mathrm{D}$ & - & - & - & $\mathrm{D}$ & - & $\mathrm{D}$ & - & + & - & - \\
\hline D-saccharic acid (F9) & - & - & - & - & - & - & - & - & - & - & - & - \\
\hline D-salicin (B5) & + & + & + & + & + & + & + & + & + & + & + & + \\
\hline D-serine (D9) & - & - & - & - & - & - & - & - & - & - & - & - \\
\hline L-serine (E9) & - & - & - & - & - & - & - & - & - & - & - & - \\
\hline D-sorbitol (D1) & $\mathrm{D}$ & - & - & - & - & - & - & - & - & - & - & + \\
\hline Stachyose (A9) & - & - & - & + & + & + & + & + & + & + & + & + \\
\hline Bromo-succinic acid (G9) & - & - & - & - & - & - & - & - & - & - & - & - \\
\hline Sucrose (A7) & + & + & + & + & + & + & + & + & + & + & + & + \\
\hline D-trehalose (A4) & + & + & + & + & + & + & + & + & + & + & + & + \\
\hline D-turanose (A8) & + & + & + & + & + & + & + & + & + & + & + & + \\
\hline Tween 40 (H1) & + & + & + & + & + & + & + & + & + & + & + & + \\
\hline
\end{tabular}


Carbon source utilization. The 12 Leuconostoc isolates representing different haplotypes were all positive for utilizing acetic acid, D-cellobiose, dextrin, D-fructose, gentiobiose, $\mathrm{N}$-acetyl-D-glucosamine, $\alpha$-D-glucose, $\beta$-methyl-D-glucoside, D-maltose, D-mannose, pectin, D-salicin, sucrose, D-trehalose, D-turanose, and Tween 40 (Table 4). Most of the 12 isolates were also positive for acetoacetic acid (except L12028 = Hap25), D-frucose (except L12056 = Hap9 and B322 = Hap19), D-gluconic acid (except L12056 = Hap9), D-melibiose (except L12177 = Hap5 and L12540 = Hap6), D-raffinose (except L12177 = Hap5, L12540 = Hap6, and L12056 = Hap9), and stachyose (except L12177 = Hap5, L12540 = Hap 6, and L12056 = Hap9). L. pseudomesenteroides isolates representing haplotypes $21,23,24,25$, and 30 were also positive for D-galactose, inosine, and $\alpha$-D-lactose.

Pathogenicity tests. In both 2014 and 2015, the Leuconostoc isolates always led to more $\operatorname{rot}(P<0.0001)$ than the water check when combined with $R$. solani strain F517 (Table 2). In 2014, 15 Leuconostoc isolates inoculated individually had measurable rot while, in 2015, all Leuconostoc isolates had measurable rot. However, in 2014, isolate L12611 was the only Leuconostoc isolate that caused significantly more rot than the water check when inoculated without $R$. solani. In 2015, all Leuconostoc isolates had measurable rot and seven Leuconostoc isolates caused significantly more rot than the water check when inoculated without $R$. solani. In 2014, the fungal check had measurable rot but it was not significantly different from the water check. In 2015, the fungal check caused rot that was significantly more than the water check. In 2014, 24 of 26 treatments with Leuconostoc combined with

TABLE 5. Root rot in sugar beet roots of the commercial cultivar B-7 inoculated with 26 Leuconostoc isolates with and without Rhizoctonia solani AG-2-2 IIIB strain F517 and analyzed by haplotype along with fungal and water checks in 2014 and 2015 Kimberly, ID field studies

\begin{tabular}{|c|c|c|}
\hline \multirow[b]{2}{*}{ Treatment ${ }^{\mathrm{y}}$} & \multicolumn{2}{|c|}{ Root $\operatorname{rot}(\mathrm{mm})^{\mathrm{x}}$} \\
\hline & 2014 & 2015 \\
\hline $5+F 517$ & $12 \mathrm{c}-\mathrm{e}$ & $40 \mathrm{a}$ \\
\hline $30+\mathrm{F} 517$ & $14 \mathrm{~cd}$ & $35 \mathrm{ab}$ \\
\hline $25+\mathrm{F} 517$ & $21 \mathrm{bc}$ & $32 \mathrm{a}-\mathrm{c}$ \\
\hline $23+\mathrm{F} 517$ & $23 \mathrm{ab}$ & $31 \mathrm{a}-\mathrm{c}$ \\
\hline $18+F 517$ & $27 \mathrm{ab}$ & $31 \mathrm{a}-\mathrm{c}$ \\
\hline $13+F 517$ & $18 \mathrm{bc}$ & $31 \mathrm{a}-\mathrm{c}$ \\
\hline $11+\mathrm{F} 517$ & $26 \mathrm{ab}$ & $31 \mathrm{bc}$ \\
\hline $21+\mathrm{F} 517$ & $17 \mathrm{bc}$ & $30 \mathrm{bc}$ \\
\hline $15+\mathrm{F} 517$ & $30 \mathrm{a}$ & $27 \mathrm{bc}$ \\
\hline $27+F 517$ & $17 \mathrm{bc}$ & $27 \mathrm{bc}$ \\
\hline $24+\mathrm{F} 517$ & $23 \mathrm{a}-\mathrm{c}$ & $26 \mathrm{bc}$ \\
\hline 9 + F517 & $17 \mathrm{bc}$ & $26 \mathrm{bc}$ \\
\hline $6+\mathrm{F} 517$ & $20 \mathrm{bc}$ & $25 \mathrm{~cd}$ \\
\hline $19+\mathrm{F} 517$ & $27 \mathrm{ab}$ & $25 \mathrm{~cd}$ \\
\hline Water + F517 & $2 \mathrm{ef}$ & $16 \mathrm{de}$ \\
\hline 18 & $1 \mathrm{f}$ & 13 ef \\
\hline 11 & 4 ef & $10 \mathrm{e}-\mathrm{g}$ \\
\hline 27 & $1 \mathrm{f}$ & $10 \mathrm{e}-\mathrm{g}$ \\
\hline 13 & $5 d-f$ & $9 \mathrm{e}-\mathrm{h}$ \\
\hline 15 & $6 \mathrm{~d}-\mathrm{f}$ & $9 \mathrm{e}-\mathrm{h}$ \\
\hline 19 & 2 ef & $9 \mathrm{e}-\mathrm{h}$ \\
\hline 24 & $0 \mathrm{f}$ & $9 \mathrm{e}-\mathrm{h}$ \\
\hline 30 & $0 \mathrm{f}$ & $8 \mathrm{e}-\mathrm{h}$ \\
\hline 25 & $0 \mathrm{f}$ & $8 \mathrm{e}-\mathrm{h}$ \\
\hline 21 & $0 \mathrm{f}$ & $8 \mathrm{f}-\mathrm{h}$ \\
\hline 23 & $1 \mathrm{f}$ & $8 \mathrm{f}-\mathrm{h}$ \\
\hline 5 & $0 \mathrm{f}$ & $6 \mathrm{f}-\mathrm{h}$ \\
\hline 6 & $0 \mathrm{f}$ & $4 \mathrm{f}-\mathrm{h}$ \\
\hline 9 & $2 \mathrm{ef}$ & $4 \mathrm{gh}$ \\
\hline Water & $0 \mathrm{f}$ & $0 \mathrm{~h}$ \\
\hline$P>F^{\mathrm{z}}$ & $<0.0001$ & $<0.0001$ \\
\hline
\end{tabular}

$\mathrm{x}$ Internal root rot measured inside a bisected sugar beet. Means followed by the same letter within a column did not differ significantly based on least square means $(\alpha=0.05)$.

y Treatment $=$ Leuconostoc haplotype with and without Rhizoctonia solani AG-2-2 IIIB strain F517. The haplotype was based on sequencing (1,437 to 1,440 bp) from the $16 \mathrm{~S}$ ribosomal RNA region. Fungal and water checks are in bold.

${ }^{\mathrm{z}} P>F$ was the probability associated with the $F$ value.
$R$. solani had significantly more rot than the fungal check. In 2015, 22 of 26 of the combination treatments induced more rot than the fungal check. In both years, all Leuconostoc isolates caused more rot when combined with $R$. solani than when inoculated alone. Therefore, the data for both years supported the conclusion that a synergistic interaction occurred between Leuconostoc and R. solani.

When the Leuconostoc treatments were combined together by haplotype in both 2014 and 2015, the haplotypes always led to more $\operatorname{rot}(P<0.0001)$ than the water check when combined with $R$. solani (Table 5). In the majority of the comparisons (13 of 14 in 2014 and 12 of 14 in 2015), the Leuconostoc haplotype $+R$. solani combination also lead to significantly more rot than the fungal check. Inoculated individually, the Leuconostoc haplotypes led to measurable rot at times but the rot was not different from water check in 2014 and not different in 2015 in 11 of 14 comparisons.

When the Leuconostoc treatments were combined together by species in both 2014 and 2015, the Leuconostoc spp. always led to more $\operatorname{rot}(P<0.0001)$ than both the water and fungal checks when combined with $R$. solani strain F517 (Table 6). Only L. mesenteroides caused measurable rot when inoculated individually in 2014 but all three species caused rot in 2015 . However, the only rot significantly different from the water check was that caused by L. mesenteroides and L. pseudomesenteroides in 2015.

In 2014, isolations from 20 rot samples inoculated with both Leuconostoc and $R$. solani were all positive for Leuconostoc but only one sample was positive for $R$. solani. In 2015, isolations from 20 rot samples inoculated with both Leuconostoc and $R$. solani were all positive for Leuconostoc and none were positive for $R$. solani. In both 2014 and 2015, isolations from six samples inoculated with only Leuconostoc spp. were positive for Leuconostoc and contained no $R$. solani. In both 2014 and 2015, the isolations from the fungal check indicated that $R$. solani could be confirmed $67 \%$ of the time but Leuconostoc spp. were also present (not unexpected because inoculations were conducted in the field and Leuconostoc is common in the environment). No rot ever occurred in the water checks; therefore, isolations were not conducted from the water checks.

\section{DISCUSSION}

Based on 203 Leuconostoc isolates collected from rot in recently harvested sugar beet roots in southern Idaho and southeastern Oregon, the following Leuconostoc spp. were found (during 2010 and 2012): L. mesenteroides (88 and $85 \%$ of isolates, respectively), L. pseudomesenteroides (6 and 15\%), L. kimchi ( 2 and $0 \%$ ), and an unrecognized Leuconostoc sp. (4 and 0\%). Based on sequencing

TABLE 6. Root rot in sugar beet roots of the commercial cultivar B-7 inoculated with 26 Leuconostoc isolates with and without Rhizoctonia solani AG-2-2 IIIB strain F517 and analyzed by Leuconostoc sp. along with fungal and water checks in 2014 and 2015 Kimberly, ID field studies

\begin{tabular}{lcc}
\hline & \multicolumn{2}{c}{${\text { Root rot }(\mathrm{mm})^{\mathrm{x}}}$} \\
\cline { 2 - 3 } Treatment $^{\mathrm{y}}$ & 2014 & 2015 \\
\hline L. kimchi + F517 & $16 \mathrm{~b}$ & $33 \mathrm{a}$ \\
L. pseudomesenteroides + F517 & $19 \mathrm{~b}$ & $31 \mathrm{a}$ \\
L. mesenteroides + F517 & $26 \mathrm{a}$ & $29 \mathrm{a}$ \\
Water + F517 & $2 \mathrm{c}$ & $16 \mathrm{~b}$ \\
L. mesenteroides & $4 \mathrm{c}$ & $9 \mathrm{bc}$ \\
L. pseudomesenteroides & $0 \mathrm{c}$ & $8 \mathrm{c}$ \\
L. kimchii & $0 \mathrm{c}$ & $5 \mathrm{~cd}$ \\
Water & $0 \mathrm{c}$ & $0 \mathrm{~d}$ \\
$P>F^{\mathrm{z}}$ & $<0.0001$ & $<0.0001$ \\
\hline
\end{tabular}

$\mathrm{x}$ Internal root rot measured inside a bisected sugar beet. Means followed by the same letter within a column did not differ significantly based on least square means $(\alpha=0.05)$.

y Treatment $=$ Leuconostoc sp. with and without Rhizoctonia solani strain F517. The Leuconostoc sp. was based on sequencing (1,437 to 1,440 bp) from the $16 \mathrm{~S}$ ribosomal RNA region. Water and fungal checks are in bold print.

${ }^{\mathrm{z}} P>F$ was the probability associated with the $F$ value. 
from the 16S rRNA region, 23 haplotypes were found but haplotype 11 (L. mesenteroides isolates) comprised 68 to $70 \%$ of the isolates both years. Pathogenicity tests revealed that representative isolates from 14 of these haplotypes led to more rot through a synergistic interaction with $R$. solani, because all Leuconostoc isolates induced more $\operatorname{rot}(P<0.0001 ; \alpha=0.05)$ when combined with $R$. solani than when inoculated alone in both years. Also, 46 of the 52 combination treatments over the 2 years had significantly more rot $(P<0.0001$; $\alpha=0.05)$ than the fungal check. Therefore, the data support the conclusion that a synergistic interaction leading to more root rot can occur between Leuconostoc and $R$. solani. However, the interaction was only evaluated against $R$. solani strain F517 under Idaho conditions. To ensure that the response is widespread, the synergistic response should be evaluated in other growing areas and additional strains of $R$. solani should be evaluated versus the Leuconostoc strains.

Bacterial root rot in sugar beet has traditionally been studied in association with Pectobacterium betavasculorum (Thomson et al.) Gardan et al. (syn. Erwinia carotovora (Jones) Bergey et al. subsp. betavasculorum Thomson et al.) and Pseudomonas spp. (Dutta et al. 2014; Gardan et al. 2003; Jacobsen 2009; Ruppel et al. 1975; Thomson et al. 1977). However, in 2008, L. mesenteroides subsp. dextranicum was also established to be associated with root rot in sugar beet and frequently associated with recently harvested roots infested with $R$. solani (Strausbaugh and Gillen 2008). A recent study in Germany confirms these earlier observations, having found the genus Leuconostoc to be associated with $92 \%$ of the recently harvested sugar beet roots with root rot (Liebe and Varrelmann 2016). The present study builds on the knowledge from these earlier studies to show that $L$. mesenteroides haplotype 11 is the primary Leuconostoc sp. associated rot in sugar beet in southern Idaho and southeastern Oregon, because it comprised 68 to $70 \%$ of the isolates. In addition, L. pseudomesenteroides and L. kimchi isolates were also shown to be associated with sugar beet root rot for the first time, although less frequently than $L$. mesenteroides. When individual isolates from these Leuconostoc spp. were inoculated with $R$. solani, they led to more rot than when they were inoculated individually. A previous study with recently harvested roots also indicated that there may be an interaction between L. mesenteroides and $R$. solani but the results were similar to a storage response rather than field results (Strausbaugh et al. 2013a).

The results in the current study represent the first field study to show that a synergistic interaction can exist between Leuconostoc spp. and $R$. solani. Other investigations studying $R$. solani on sugar beet and other crops have been focused on investigating bacteria in an effort to develop a biocontrol to limit disease development by the fungus (De Curtis et al. 2010; Gkarmiri et al. 2015; Heydari and Misaghi 2003; Hua and Höfte 2015; Lovic et al. 1993; Mendes et al. 2011; Olorunleke et al. 2015; Postma and Schilder 2015; Postma et al. 2010; Schillinger and Paulitz 2014; Solanki et al. 2012; Weller et al. 2002; Yin et al. 2013; Zachow et al. 2011).

Leuconostoc is a heterofermentative bacterium known to be important in the initial phase of fermentation but it usually is superseded by other bacteria and yeast (Adesogan et al. 2003; Amoa-Awua et al. 2007; Breidt 2004; Gardner et al. 2001; Jung et al. 2012). A number of these other bacteria and yeast associated with root rot in sugar beet roots have been shown to slow down rot by L. mesenteroides and inhibit $R$. solani (Lovic et al. 1993; Strausbaugh and Gillen 2008). The competition provided by these bacteria and yeast may help explain why $R$. solani is largely restricted to tissue near the root surface (Strausbaugh and Eujayl 2012; Strausbaugh and Gillen 2008; Strausbaugh et al. 2013a,b). This competition also makes it problematic to cleanly isolate $R$. solani and Leuconostoc spp. from root tissue even when using semiselective media (Strausbaugh et al. 2013a). Because of competition from fast-growing contaminants, our success rate for Leuconostoc isolations from recently harvested commercial roots was $63 \%$, while isolations from the fungal checks in the field study was $67 \%$. An $R$. solani reisolation success rate of $66 \%$ was found in another study when roots were taken from the field and inoculated with $R$. solani (Strausbaugh et al. 2013a). If collecting isolates is not a necessary part of the study, than utilizing a recently developed microarray may be a more reliable way to prove that Leuconostoc spp. and $R$. solani are associated with the rotting sugar beet roots (Liebe et al. 2016). Another advantage of using a DNAbased microarray approach may be to limit one's exposure to Leuconostoc spp. Leuconostoc spp., including L. mesenteroides and $L$. pseudomesenteroides, are emerging as human pathogens that can lead to severe infections, particularly in immunocompromised individuals (Albanese et al. 2006; Bou et al. 2008; Deng et al. 2012; Kumudhan and Mars 2004; Shin et al. 2011; Taneja et al. 2005; Taşkapilioğlu et al. 2011; Tholpady et al. 2010; Wong et al. 2012; Yang et al. 2015). However, considering the rarity of Leuconostoc infections in people and the large presence of Leuconostoc spp. in foods and the environment, they are generally recognized as safe (Hemme 2012).

RRCR appears to be on the rise in a number of growing areas worldwide; therefore, developing management options is a primary concern (Buddemeyer et al. 2004; Buhre et al. 2009; Führer Ithurrart et al. 2004; Ohkura et al. 2009). The management of RRCR through host resistance would be desirable and likely the most costeffective control measure (Panella 2005). However, most commercial sugar beet cultivars provide only low to intermediate levels of resistance (Strausbaugh et al. 2013a). In addition, cultivars that do contain good resistance typically do not have the yield and resistance to other diseases necessary to make it through the cultivar approval process (Strausbaugh et al. 2013b). Developing resistant cultivars is problematic, because resistance is quantitative and the cultivars frequently suffer from yield drag (Hecker and Ruppel 1975; Lein et al. 2008; Panella 2005). Also complicating the screening process for resistance in sugar beet are the different strains of $R$. solani and their interactions with different Leuconostoc spp. (Strausbaugh et al. 2013b). The use of crop rotation (Buddemeyer et al. 2004; Buhre et al. 2009; Engelkes and Windels 1996; Kluth and Varrelmann 2010; Ruppel 1985; Rush and Winter 1990) and fungicides (Bolton et al. 2010; Kiewnick et al. 2001; Kirk et al. 2008; Stump et al. 2004; Windels and Brantner 2005) can also help limit RRCR; however, unacceptable levels of rot still frequently occur. Perhaps investigations into what leads to the synergistic interaction between $R$. solani and Leuconostoc spp. may allow for a better understanding of the rot process and additional control measures.

\section{ACKNOWLEDGMENTS}

These data support the objectives for the United States Department of Agriculture CRIS project 5368-21220-003-00D. We thank the Amalgamated Sugar Co., LLC; Beet Sugar Development Foundation; and Snake River sugar beet growers for supporting our research work; and J. Reed, D. Kenney, and T. Keeth for their technical support efforts. Mention of trade names or commercial products in this article is solely for the purpose of providing scientific information and does not imply recommendation or endorsement by the United States Department of Agriculture.

\section{LITERATURE CITED}

Adesogan, A. T., Salawu, M. B., Ross, A. B., Davies, D. R., and Brooks, A. E. 2003. Effect of Lactobacillus buchneri, Lactobacillus fermentum, Leuconostoc mesenteroides, or a chemical additive on the fermentation, aerobic stability, and nutritive value of crimped wheat grains. J. Dairy Sci. 86:1789-1796.

Albanese, A., Spanu, T., Sali, M., Novegno, F., D’Inzeo, T., Santangelo, R., Mangiola, A., Anile, C., and Fadda, G. 2006. Molecular identification of Leuconostoc mesenteroides as a cause of brain abscess in an immunocompromised patient. J. Clin. Microbiol. 44:3044-3045.

Amoa-Awua, W. K., Sampson, E., and Tano-Debrah, K. 2007. Growth of yeasts, lactic and acetic acid bacteria in palm wine during tapping and fermentation from felled oil palm (Elaeis guineensis) in Ghana. J. Appl. Microbiol. 102:599-606.

Baker, G. C., Smith, J. J., and Cowan, D. A. 2003. Review and re-analysis of domain specific 16S primers. J. Microbiol. Methods 55:541-555. 
Benkerroum, N., Misbah, M., Sandine, W. E., and Elaraki, A. T. 1993. Development and use of a selective medium for isolation of Leuconostoc spp. from vegetables and dairy products. Appl. Environ. Microbiol. 59:607-609.

Bolton, M. D., Panella, L., Campbell, L., and Khan, M. 2010. Temperature, moisture, and fungicide effects in managing Rhizoctonia root and crown rot of sugar beet. Phytopathology 100:689-697.

Bou, G., Saleta, J. L., Nieto, J. A. S., Tomás, M., Valdezate, S., Sousa, D., Lueiro, F., Villanueva, R., Pereira, M. J., and Llinares, P. 2008. Nosocomial outbreaks caused by Leuconostoc mesenteroides subsp. mesenteroides. Emerg. Infect. Dis. 14:968-971.

Breidt, F., Jr. 2004. A genomic study of Leuconostoc mesenteroides and the molecular ecology of sauerkraut fermentations. J. Food Sci. 69:FMS30-FMS33.

Buddemeyer, J., Pfähler, B., Peterson, J., and Märländer, B. 2004. Genetic variation in susceptibility of maize to Rhizoctonia solani (AG 2-2IIIB)-Symptoms and damage under field conditions in Germany. J. Plant Dis. Prot. 111:521-533.

Buhre, C., Kluth, C., Bürcky, K., Märländer, B., and Varrelmann, M. 2009. Integrated control of root and crown rot in sugar beet: Combined effects of cultivar, crop rotation, and soil tillage. Plant Dis. 93:155-161.

Büttner, G., Pfähler, B., and Märländer, B. 2004. Greenhouse and field techniques for testing sugar beet for resistance to Rhizoctonia root and crown rot. Plant Breed. 123:158-166.

Cai, Y., Kumai, S., Ogawa, M., Benno, Y., and Nakase, T. 1999. Characterization and identification of Pediococcus species isolated from forage crops and their application for silage preparation. Appl. Environ. Microbiol. 65: 2901-2906.

Cescutti, P., Kallioinen, A., Impallomeni, G., Toffanin, R., Pollesello, P., Leisol, M., and Eerikäinen, T. 2005. Structure of the exopolysaccharide produced by Enterobacter amnigenus. Carbohydr. Res. 340:439-447.

Chen, Y.-S., Yanagida, F., and Shinohara, T. 2005. Isolation and identification of lactic acid bacteria from soil using an enrichment procedure. Lett. Appl. Microbiol. 40:195-200.

Cogan, T. M., and Jordan, K. N. 1994. Metabolism of Leuconostoc bacteria. J. Dairy Sci. 77:2704-2717.

Coloqhoun, J. A. 1997. Discovery of deep-sea actinomycetes. Ph.D. dissertation, Research School of Biosciences, University of Kent, Canterbury, UK.

Conn, K. E., Ogawa, J. M., Manji, B. T., and Adaskveg, J. E. 1995. Leuconostoc mesenteroides subsp. mesenteroides, the first report of a coccoid bacterium causing a plant disease. Phytopathology 85:593-599.

De Curtis, F., Lima, G., Vitullo, D., and De Cicco, V. 2010. Biocontrol of Rhizoctonia solani and Sclerotium rolfsii on tomato by delivering antagonistic bacteria through a drip irrigation system. Crop Prot. 29:663-670.

Deng, Y., Zhang, Z., Xie, Y., Xiao, Y., Kang, M., and Fan, H. 2012. A mixed infection of Leuconostoc lactis and vancomycin-resistant Enterococcus in a liver transplant recipient. J. Med. Microbiol. 61:1621-1624.

Dutta, B., Ingram, T., Gitaitis, R. D., Langston, D. B., Brenneman, T., Webster, T. M., and Davis, R. F. 2014. First report of bacterial blight of sugar beet caused by Pseudomonas syringae pv. aptata in Georgia, USA. Plant Dis. 98:1423

Engelkes, C. A., and Windels, C. E. 1996. Susceptibility of sugar beet and beans to Rhizoctonia solani AG-2-2 IIIB and AG-2-2IV. Plant Dis. 80:1413-1417.

Führer Ithurrart, M. E., Büttner, G., and Peterson, J. 2004. Rhizoctonia root rot in sugar beet (Beta vulgaris ssp. altissima)-Epidemiological aspects in relation to maize (Zea mays) as a host plant. J. Plant Dis. Prot. 111:302-312.

Gardan, L., Gouy, C., Christen, R., and Samson, R. 2003. Elevation of three subspecies of Pectobacterium carotovorum to species level: Pectobacterium atrospecticum sp. nov., Pectobacterium betavasulorum sp. nov., and Pectobacterium wasabiae sp. nov. Int. J. Syst. Evol. Microbiol. 53:381-391

Gardner, N. J., Savard, T., Obermeier, P., Caldwell, G., and Champagne, C. P. 2001. Selection and characterization of mixed starter cultures for lactic acid fermentation of carrot, cabbage, beet and onion vegetable mixtures. Int. J. Food Microbiol. 64:261-275.

Gkarmiri, K., Finlay, R. D., Alström, S., Thomas, E., Cubeta, M. A., and Högberg, N. 2015. Transcriptomic changes in the plant pathogenic fungus Rhizoctonia solani AG-3 in response to the antagonistic bacteria Serratia proteamaculans and Serratia plymuthica. BMC Genomics 16:630.

Hall, T. 1999. BioEdit: A user-friendly biological science sequence alignment editor and analysis program for Windows 95/98/NT. Nucleic Acids Symp. Ser. 41:95-98.

Hecker, R. J., and Ruppel, E. G. 1975. Inheritance of resistance to Rhizoctonia root rot in sugar beet. Crop Sci. 15:487-490.

Hemme, D. 2012. Leuconostoc and its use in dairy technology. Pages 73-108 in: Handbook of Animal-Based Fermented Food and Beverage Technology. Y. H. Hui, ed. CRC Press, New York.

Heydari, A., and Misaghi, I. J. 2003. The role of rhizosphere bacteria in herbicide-mediated increase in Rhizoctonia solani-induced cotton seedling damping-off. Plant Soil 257:391-396.

Holt, J. G., Krieg, N. R., Sneath, P. H. A., Staley, J. T., and Williams, S. T., eds. 1994. Bergy's Manual of Determinative Bacteriology, 9th ed. Williams and Wilkins, Baltimore, MD.
Hua, G. K. H., and Höfte, M. 2015. The involvement of phenazines and cyclic lipopeptide sessilin in biocontrol of Rhizoctonia root rot on bean (Phaseolus vulgaris) by Pseudomonas sp. CMR12a is influenced by substrate composition. Plant Soil 388:243-253.

Jacobsen, B. J. 2009. Bacterial vascular necrosis and rot. Pages 58-59 in: Compendium of Beet Diseases and Pests. R. M. Harveson, L. E. Hanson, and G. L. Hein, eds. American Phytopathological Society, St. Paul, MN.

Jung, J. Y., Lee, S. H., Lee, H. J., Seo, H.-Y., Park, W.-S., and Jeon, C. O. 2012. Effects of Leuconostoc mesenteroides starter cultures on microbial communities and metabolites during kimchi fermentation. Int. J. Food Microbiol. 153:378-387.

Kiewnick, S., Jacobsen, B. J., Braun-Kiewnick, A., Eckhoff, J. L. A., and Bergman, J. W. 2001. Integrated control of Rhizoctonia crown and root rot of sugar beet with fungicides and antagonistic bacteria. Plant Dis. 85:718-722.

Kirk, W. W., Wharton, P. S., Schafer, R. L., Tumbalam, P., Poindexter, S., Guza, C., Fogg, R., Schlatter, T., Stewart, J., Hubbell, L., and Ruppal, D. 2008. Optimizing fungicide timing for the control of Rhizoctonia crown and root rot of sugar beet using soil temperature and plant growth stages. Plant Dis. 92:1091-1098.

Kluth, C., Buhre, C., and Varrelmann, M. 2010. Susceptibility of intercrops to infection with Rhizoctonia solani AG 2-2 IIIB and influence on subsequently cultivated sugar beet. Plant Pathol. 59:683-692.

Kluth, C., and Varrelmann, M. 2010. Maize genotype susceptibility to Rhizoctonia solani and its effect on sugar beet crop rotations. Crop Prot. 29:230-238.

Kumudhan, D., and Mars, S. 2004. Leuconostoc mesenteroides as a cause of post-operative endophthalmitis-A case report. Eye 18:1023-1024.

Larkin, M. A., Blackshields, G., Brown, N. P., Chenna, R., McGettigan, P. A., McWilliam, H., Valentin, F., Wallace, I. M., Wilm, A., Lopez, R., Thompson, J. D., Gibson, T. J., and Higgins, D. G. 2007. Clustal W and Clustal X version 2.0. Bioinformatics 23:2947-2948.

Lein, J. C., Sagstetter, C. M., Schulte, D., Thurau, T., Varrelmann, M., Saal, B., Koch, G., Borchardt, D. C., and Jung, C. 2008. Mapping of Rhizoctonia root rot resistance genes in sugar beet using pathogen response-related sequences as molecular markers. Plant Breed. 127:602-611.

Liebe, S., Christ, D. S., Ehricht, R., and Varrelmann, M. 2016. Development of a DNA microarray based assay for the detection of sugar beet root rot pathogens. Phytopathology 106:76-86.

Liebe, S., and Varrelmann, M. 2016. Effect of environment and sugar beet genotype on root rot development and pathogen profile during storage. Phytopathology 106:65-75.

Lopez-Garcia, P., Moreira, D., Lopez-Lopez, A., and Rodriquez-Valera, F. 2001. A novel haloarchaeal-related lineage is widely distributed in deep oceanic regions. Environ. Microbiol. 3:72-78.

Lovic, B., Heck, C., Gallian, J. J., and Anderson, A. J. 1993. Inhibition of the sugarbeet pathogens Phoma betae and Rhizoctonia solani by bacteria associated with sugarbeet seeds and roots. J. Sugar Beet Res. 30:169-184.

Martínez-Murcia, A. J., Acinas, S. G., and Rodriguez-Valera, F. 1995. Evaluation of prokaryotic diversity by restrictase digestion of $16 \mathrm{~S}$ rDNA directly amplified from hypersaline environments. FEMS Microbiol. Ecol. 17: 247-255.

Mendes, R., Kruijt, M., de Bruijn, I., Dekkers, E., van der Voort, M., Schneider, J. H. M., Piceno, Y. M., DeSantis, T. Z., Andersen, G. L., Bakker, P. A. H. M., and Raaijmakers, J. M. 2011. Deciphering the rhizosphere microbiome for disease-suppressive bacteria. Science 332: 1097-1100.

Ohkura, M., Abawi, G. S., Smart, C. D., and Hodge, K. T. 2009. Diversity and aggressiveness of Rhizoctonia solani and Rhizoctonia-like fungi on vegetables in New York. Plant Dis. 93:615-624.

Olorunleke, F. E., Hua, G. K. H., Kieu, N. P., Ma, Z., and Höfte, M. 2015. Interplay between orfamides, sesslins and phenazines in the control of Rhizoctonia diseases by Pseudomonas sp. CMR12a. Environ. Microbiol. Rep. 7:774-781.

Orberg, P. K., and Sandine, W. E. 1984. Common occurrence of plasmid DNA and vancomycin resistance in Leuconostoc spp. Appl. Environ. Microbiol. 48:1129-1133.

Panella, L. 2005. Root rots. Pages 95-100 in: Genetics and Breeding of Sugar Beet. E. Biancardi, L. G. Campbell, G. N. Skaracis, and M. de Biaggi, eds. Science Publishers, Enfield, NH.

Pfähler, B., and Petersen, P. 2004. Rapid greenhouse screening of maize for resistance to Rhizoctonia solani AG2-2IIIB. J. Plant Dis. Prot. 111:292-301.

Postma, J., Nijhuis, E. H., and Yassin, A. F. 2010. Genotypic and phenotypic variation among Lysobacter capsici strains isolated from Rhizoctonia suppressive soils. Syst. Appl. Microbiol. 33:232-235.

Postma, J., and Schilder, M. T. 2015. Enhancement of soil suppressiveness against Rhizoctonia solani in sugar beet by organic amendments. Appl. Soil Ecol. 94:72-79.

Reysenbach, A.-L., and Pace, N. R. 1995. Pages 101-107 in: Archea: A Laboratory Manual-Thermophiles. F. T. Robb and A. R. Place, eds. Cold Spring Harbor Laboratory Press, Cold Spring Harbor, NY. 
Reysenbach, A.-L., Wickham, G. S., and Pace, N. R. 1994. Phylogenetic analysis of the hyperthermophilic pink filament community in Octopus Spring, Yellowstone National Park. Appl. Environ. Microbiol. 60:2113-2119.

Ronquist, F., and Huelsenbeck, J. P. 2003. MrBayes 3: Bayesian phylogenetic inference under mixed models. Bioinformatics 19:1572-1574.

Rudi, K., Skulberg, O. M., Larsen, F., and Jacoksen, K. S. 1997. Strain classification of oxyphotobacteria in clone cultures on the basis of 16S rRNA sequences from variable regions V6, V7, and V8. Appl. Environ. Microbiol. 63:2593-2599.

Ruppel, E. G. 1985. Susceptibility of rotation crops to a root rot isolate of Rhizoctonia solani from sugar beet and survival of the pathogen in crop residues. Plant Dis. 69:871-873.

Ruppel, E. G., Harrison, M. D., and Nielson, A. K. 1975. Occurrence and cause of bacterial vascular necrosis and soft rot of sugarbeet in Washington. Plant Dis. Rep. 59:837-840.

Rush, C. M., and Winter, S. R. 1990. Influence of previous crops on Rhizoctonia root and crown rot of sugar beet. Plant Dis. 74:421-425.

Schillinger, W. F., and Paulitz, T. C. 2014. Natural suppression of Rhizoctonia bare patch in a long-term no-till cropping systems experiment. Plant Dis. 98:389-394.

Server-Busson, C., Foucaud, C., and Leveau, J.-Y. 1999. Selection of dairy Leuconostoc isolates for important technological properties. J. Dairy Res. 66:245-256.

Shin, J., Her, M., Moon, C., Kim, D., Lee, S., and Jung, S. 2011. Leuconostoc bacteremia in a patient with amyloidosis secondary to rheumatoid arthritis and tuberculosis arthritis. Mod. Rheumatol. 21:691-695.

Solanki, M. K., Robert, A. S., Singh, R. K., Kumar, S., Pandey, A. K., Srivastava, A. K., and Arora, D. K. 2012. Characterization of mycolytic enzymes of Bacillus strains and their bio-protection role against Rhizoctonia solani in tomato. Curr. Microbiol. 65:330-336.

Strausbaugh, C. A., and Eujayl, I. A. 2012. Influence of sugarbeet tillage systems on the Rhizoctonia-bacterial root rot complex. J. Sugar Beet Res. 49:57-78.

Strausbaugh, C. A., Eujayl, I. A., and Foote, P. 2010. Sugarbeet cultivar evaluation for bacterial root rot. J. Sugar Beet Res. 47:51-64.

Strausbaugh, C. A., Eujayl, I. A., and Foote, P. 2013a. Selection for resistance to the Rhizoctonia-bacterial root rot complex in sugar beet. Plant Dis. 97:93-100.

Strausbaugh, C. A., Eujayl, I. A., and Panella, L. W. 2013b. Interaction of sugar beet host resistance and Rhizoctonia solani AG-2-2 IIIB strains. Plant Dis. 97:1175-1180.

Strausbaugh, C. A., Eujayl, I. A., Panella, L. W., and Hanson, L. E. 2011a. Virulence, distribution and diversity of Rhizoctonia solani from sugar beet in Idaho and Oregon. Can. J. Plant Pathol. 33:210-226.

Strausbaugh, C. A., and Gillen, A. M. 2008. Bacteria and yeast associated with sugar beet root rot at harvest in the Intermountain West. Plant Dis. 92:357-363.

Strausbaugh, C. A., and Gillen, A. M. 2009. Sugar beet root rot at harvest in the US Intermountain West. Can. J. Plant Pathol. 31:232-240.

Strausbaugh, C. A., Rearick, E., Eujayl, I., and Foote, P. 2011b. Influence of Rhizoctonia-bacterial root rot complex on storability of sugarbeet. J. Sugar Beet Res. 48:155-181.

Stump, W. L., Franc, G. D., Harveson, R. M., and Wilson, R. G. 2004. Strobilurin fungicide timing for Rhizoctonia root and crown rot suppression in sugarbeet. J. Sugar Beet Res. 41:17-37.
Taheri, P., and Tarighi, S. 2012. Genetic and virulence analysis of Rhizoctonia spp. Associated with sugar beet root and crown rot in the northeastern region of Iran. Plant Dis. 96:398-408.

Tajima, K., Nagamine, T., Matsui, H., Nakamura, M., and Aminov, R. I. 2001. Phylogenetic analysis of archeal 16S rRNA libraries from the rumen suggests the existence of a novel group of archea not associated with known methanogens. FEMS Microbiol. Lett. 200:67-72.

Tallgren, A. H., Airaksinen, U., von Weissenberg, R., Ojamo, H., Kuusisto, J., and Leisola, M. 1999. Exopolysaccharide-producing bacteria from sugar beets. Appl. Environ. Microbiol. 65:862-864.

Tamura, K., Peterson, D., Peterson, N., Stecher, G., Nei, M., and Kumar, S. 2011. MEGA5: Molecular evolutionary genetics analysis using maximum likelihood, evolutionary distance, and maximum parsimony methods. Mol. Biol. Evol. 28:2731-2739.

Taneja, N., Rani, P., Emmanuel, R., Khudaier, B. Y., Sharma, S. K., Tewari, R., and Sharma, M. 2005. Nosocomial urinary tract infection due to Leuconostoc mesenteroides at a tertiary care center in north India. Indian J. Med. Res. 122:178-179.

Taşkapilioğlu, Ö., Bahar, A., Yilmaz, E., and Bakar, M. 2011. Nosocomial Leuconostoc pseudomensenteroides meningitis: A case report and review of the literature. Balkan Med. J. 28:216-218.

Tholpady, S. S., Sifri, C. D., Sawyer, R. G., Hazen, K. C., Pruett, T. L., and Bonatti, H. 2010. Leuconostoc pseudomesenteroides blood stream infection following liver transplantation. Ann. Transplant. 15:61-66.

Thomson, S. V., Schroth, M. N., Hills, F. J., Whitney, E. D., and Hildebrand, D. C. 1977. Bacterial vascular necrosis and rot of sugarbeet: General description and etiology. Phytopathology 67:1183-1189.

Weller, D. M., Raaijmakers, J. M., McSpadden Gardener, B. B., and Thomashow, L. S. 2002. Microbial populations responsible for specific soil suppressiveness to plant pathogens. Annu. Rev. Phytopathol. 40:309-348.

Windels, C. E., and Brantner, J. R. 2005. Early-season application of azoxystrobin to sugarbeet for control of Rhizoctonia solani AG 4 and AG 2-2. J. Sugar Beet Res. 42:1-16.

Wong, D. W., Yang, W., and Vielemeyer, O. 2012. Catheter-related Leuconostoc bacteraemia in a pregnant HIV-infected woman. J. Med. Cases 3: 331-333.

Yang, C., Wang, D., Zhou, Q., and $\mathrm{Xu}$, J. 2015. Bacteremia due to vancomycin-resistant Leuconostoc lactis in patient with pneumonia and abdominal infection. Am. J. Med. Sci. 349:282-283.

Yin, C., Hulbert, S. H., Schroeder, K. L., Mavrodi, O., Mavrodi, D., Dhingra, A., Schillinger, W. F., and Paulitz, T. C. 2013. Role of bacterial communities in the natural suppression of Rhizoctonia solani bare patch disease of wheat (Triticum aestivum L.). Appl. Environ. Microbiol. 79:7428-7438.

Zachow, C., Grosch, R., and Berg, G. 2011. Impact of biotic and a-biotic parameters on structure and function of microbial communities living on sclerotia of the soil-borne pathogenic fungus Rhizoctonia solani. Appl. Soil Ecol. 48:193-200.

Zarazaga, M., Sáenz, Y., Portillo, A., Tenorio, C., Ruiz-Larrea, F., Del Campo, R., Baquero, F., and Torres, C. 1999. In vitro activities of ketolide HMR3647, macrolides, and other antibiotics against Lactobacillus, Leuconostoc, and Pediococcus isolates. Antimicrob. Agents Chemother. 43: 3039-3041. 